\title{
Pools 'on the rocks': freshwater rock pools as model system in ecological and evolutionary research
}

\author{
Luc Brendonck $^{1, *}$, Merlijn Jocque ${ }^{1,2}$, Ann Hulsmans ${ }^{1}$ and Bram Vanschoenwinkel ${ }^{1}$ \\ ${ }^{1}$ K.U.Leuven, Laboratory of Aquatic Ecology and Evolutionary Biology, Ch. Debériotstraat 32, B-3000 Leuven, \\ Belgium. \\ ${ }^{2}$ Central Laboratory of General Ecology, Bulgarian Academy of Sciences, 2 Yuri Gagarin Street, 1113 Sofia, \\ Bulgaria. \\ *Corresponding author: Luc.Brendonck@bio.kuleuven.
}

Received: 29/12/09

Accepted: $12 / 1 / 10$

\begin{abstract}
Pools 'on the rocks': freshwater rock pools as model system in ecological and evolutionary research

Rock pools inarguably exhibit a number of characteristics which make them attractive as a model system in ecological and evolutionary research. They are usually small, pristine, clearly delineated and structurally simple systems that occur on a global scale. They facilitate the quantification of important population and community structuring processes which are often hard or impossible to quantify in larger more complex systems. Basic properties and spatial configuration of rock pools also closely resemble theoretical metapopulation and metacommunity models. Due to the simple morphometry of rock pool basins and the lack of any groundwater interactions, rock pool hydrologies are simple allowing to reliably reconstruct the disturbance regime against which patterns of variation in life histories, population genetics, species diversity and community structure can be interpreted.
\end{abstract}

Key words: Rock pools, temporary waters, model system, evolutionary ecology, metacommunity ecology, metapopulation biology.

\section{RESUMEN}

Pozas en las rocas: Un sistema modelo para investigaciones evolutivo-ecológicas

Sin lugar a dudas las pozas en rocas presentan numerosas características que las hacen atractivas para su uso como sistema modelo en la investigación evolutivo-ecológica. Normalmente son sistemas vírgenes de pequeño tamaño, estructuralmente sencillos y claramente delineados, que se encuentran a escala global. Permiten la cuantificación de importantes procesos estructuradores de poblaciones y comunidades que, a menudo, son muy difíciles o imposibles de cuantificar en sistemas mayores más complejos. Las propiedades básicas y la configuración espacial de las pozas en rocas también muestran una estrecha semejanza con los modelos teóricos de metapoblación y metacomunidad. Debido a la morfometría simple de las cubetas de estas pozas y a la carencia de interacciones con las aguas subterráneas, las hidrologías de estas pozas son de poca complejidad, lo que permite reconstruir con fiabilidad el régimen de perturbación determinante de los patrones de variación de los ciclos de vida de los organismos, de la genética de poblaciones, diversidad de especies y estructura de comunidades.

Palabras clave: Pozas en rocas, aguas temporales, sistema modelo, ecología evolutiva, ecología de metacomunidades, biología de metapoblaciones. 


\section{INTRODUCTION}

Advances in research are best attained with the use of "model systems": study subjects that are selected for intensive multidisciplinary study based on specific advantages they offer. The combined efforts result in an accelerated understanding of processes and are probably the most efficient way to get a holistic understanding of life. Typically model systems are organisms such as the zebrafish Danio rerio, the flour beetle Tribolium $s p$., the waterflea Daphnia, etc. Surprisingly, until now, no habitat is generally accepted as model system. The main difficulty here lies in the limited geographic occurrence of most candidate habitats (e.g. bromeliads) or the high environmental variability on different continents limiting the comparability of results (e.g. ponds).

There is, however, a need for a model habitat as study system which allows for testing of general processes in a simplified, but realistic setting. The potentials of small aquatic systems such as ponds and pools for studies in ecology, biogeography and evolutionary biology have been underlined in several key publications (Blaustein \& Schwartz, 2001; Srivastava et al., 2004; De Meester et al., 2005). Especially the fact that they are small and manageable, easy to sample and usually occur in large numbers along important ecological gradients such as latitude, altitude, nutrient loading and connectivity has contributed to the popularity of their use as study systems.

The increasing awareness that a large number of species today occur as discrete populations arranged in a matrix of unsuitable habitat has stimulated increasingly more researchers to use insular habitat systems to study the effects of dispersal and the spatial configuration of habitat patches on characteristics of populations (genetic diversity, population turnover; metapopulation ecology) and communities (diversity, community assembly, stability; metacommunity ecology) (Gilpin \& Hanski 1991; Wilson 1992; Leibold et al., 2004). Species coexistence patterns in metacommunities are expected to be dominantly affected by dispersal rates (Mouquet \& Loreau, 2002, 2003) and patch disturbance regimes (Ostman et al., 2006; Hughes et al., 2007). Empiri- cal support for the different developed theoretical models and metacommunity paradigms is, however, still relatively scant (Leibold et al., 2004; Holyoak \& Loreau, 2006; Urban et al., 2008).

Natural aquatic 'micro-and mesocosms', such as pitcher plants, tree holes and rock pools provide suitable settings to test metapopulation and metacommunity theory as they occur as discrete units along gradients of isolation and connectivity (e.g. Ellis et al., 2006; Vanschoenwinkel et al., 2007; Ng et al., 2009; Pandit et al., 2009). Temporary rock pools share the advantages of small size, replication and manipulability (Blaustein \& Schwartz 2001) with other small water bodies but have the additional benefit that they are much older systems and house more diverse communities (Jocque et al., 2006). Besides the fact that isolation of rock pools can easily be measured they also have the additional advantage that patch disturbance regime is primarily determined by the hydroregime of the pools, which can easily be quantified using simple hydrological models (Hulsmans et al., 2008; Vanschoenwinkel et al., 2009a).

Freshwater rock pool ecosystems include all types of depressions occurring on rocky substrates which (periodically) hold freshwater (Fig. 1). Most of these habitats rely on precipitation for filling, while others may be fed by flooding rivers or ground water (e.g. quarry ponds). Here we only focus on the typical rain fed rock pools which house specialized communities adapted to the often unpredictable patterns of drying and flooding.

In the light of the increasing search for an appropriate model system for (meta) community ecology we here discuss the potential of freshwater rock pools to fill this lacuna. We do this by first highlighting some unique features of rock pools, especially focusing on their spatial organization, physical structure and hydrological disturbance regime that impact ecological processes both at the species and community level. Next, we present some examples of research that tackled questions in population genetics, community ecology and evolutionary biology using these particular features. In the text boxes we present information on proven methods to study particular features of rock pool habitats and their inhabitants. The current manuscript is comple- 


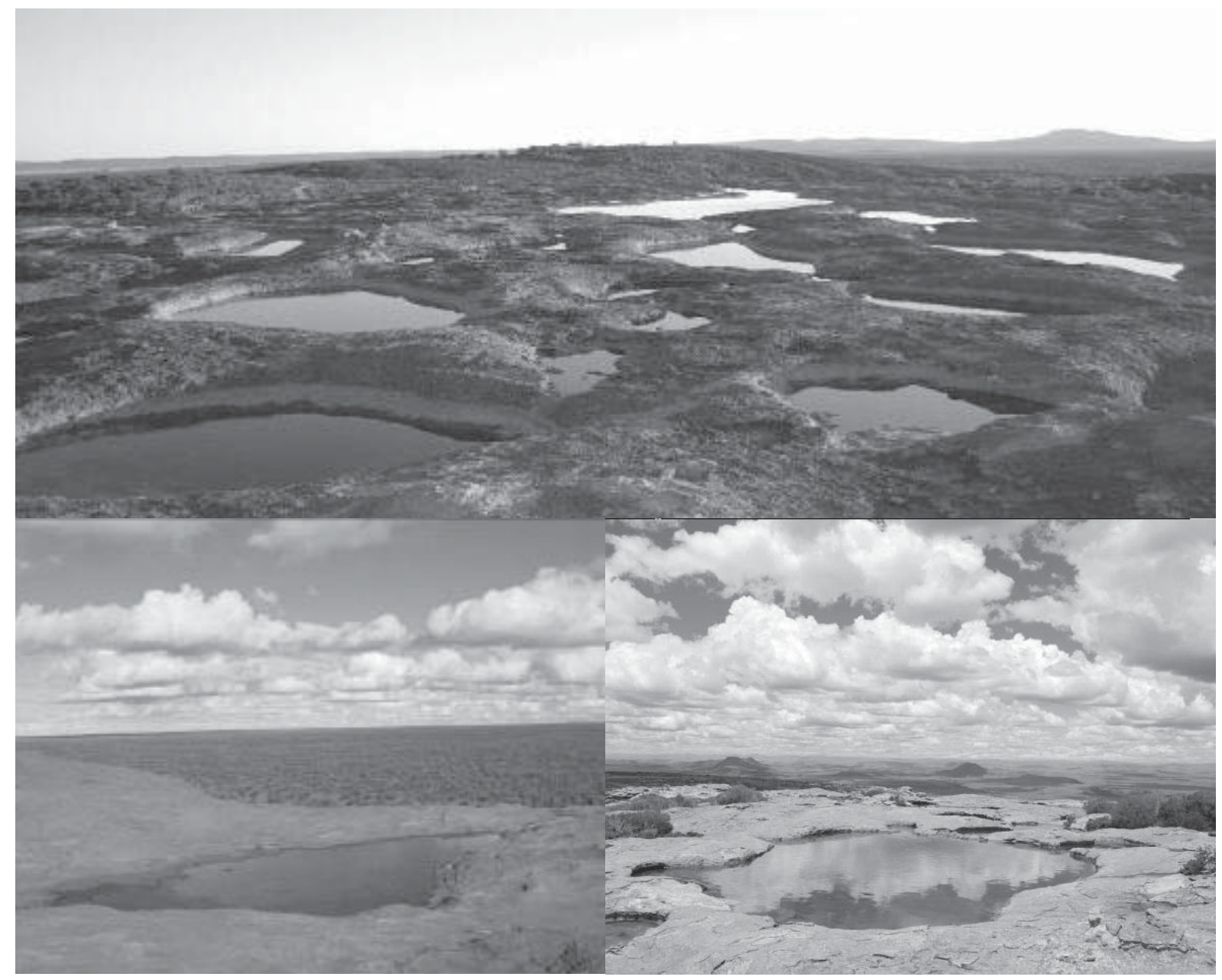

Figure 1. Granite rock pool cluster on top of Walga Rock (Western Australia) (top picture); Isolated rock pool on Walloo Rock (Western Australia) (bottom left); Sandstone rock pool on Thaba Phatshwa (South Africa) (bottom right). Grupo de pozas en rocas de granito en la cima de Walga Rock (Australia Occidental) (fotografía superior); poza rocosa aislada sobre Walloo Rock (Australia Occidental) (inferior izquierda); pozas en rocas de arenisca sobre Thaba Phatshwa (África Meridional) (inferior derecha).

mentary to Jocque et al. (2010) that presents an overview of world wide faunal diversity patterns in rock pools and a discussion of their conservation. The same study also revises the chemical and physical characteristics of rock pools and presents their importance for phylogeographical and biogeographical studies.

\section{HYDROREGIME}

Freshwater rock pools in most cases are temporary habitats. Rock pools occurring in semi-arid regions with low rainfall and high evaporation rate such as in southeast Botswana, for example, are described as highly unpredictable in both timing and length of the inundation period (Brendonck et al., 1998; 2000a). The length of the hydroperiod averaged from several days up to little more than a month (Brendonck et al., 2000a). Rock pools in more temperate regions can be semi permanent, remaining inundated for several seasons (Jocque et al., 2010).

The hydroregime (Hulsmans et al., 2008) is an important but complex variable, which to a large extent determines the composition, structure and 
diversity of rock pool communities as well as life history strategies of populations. Hydroregime encompasses a set of variables including the average length a pool remains inundated (hydroperiod) and variance on this statistic, together with the timing, frequency and periodicity of inundations (Hulsmans et al., 2008; Vanschoenwinkel et al., 2009a). Time stress and particularly the mortality associated with desiccation can be considered as a severe form of disturbance (Therriault \& Kolasa, 2001). Particularly desiccation frequency and the prevalence of very short inundations (too short for reproduction) are directly related to the disturbance regime of the rock pool habitat, as is variably experienced by different local biota.

Studies on temporary water bodies often include some hydrological monitoring (e.g. presence/absence of water) (Fischer et al., 2000), but the quantity and quality of most observations are typically inadequate to quantitatively characterize long term hydrological dynamics (but see Brooks, 2004; Bauder, 2005). Hydroregime cannot be reliably estimated on short term observations, but often it is possible to use proxies for a good approximation. Morphometrical variables are commonly used as proxies for hydroregime (Marcus \& Weeks, 1997), but care should be taken for collinearity of different contributing hydrological variables as this may prevent unequivocal explanation of measured responses. In rock pools the use of morphometrical basin properties (e.g. depth) as proxies for aspects of pool hydroregime, such as hydroperiod, can be justified (Jocque et al., 2006). Basin depth and even pool area commonly tend to be correlated variables related to hydrological stability such as average and maximum hydroperiod (Altermatt et al., 2009). Still, even weak collinearity between morphometry and hydrology may prevent unequivocal explanation of measured responses in terms of habitat size, habitat duration or patch disturbance (Vanschoenwinkel et al., 2009a).

A robust, quantitative description of hydroregime requires the incorporation of daily, seasonal, and inter annual components of hydrological variation over an ecologically relevant time frame. Long time series would permit inclusion of effects of cyclic climate phenomena (for example, El Nino-Southern Oscillation, ENSO; North Atlantic Oscillation, NAO) and anthropogenic climate change on hydroregime characteristics (Pfeifer et al., 2006). Although capabilities for in situ observation continue to improve rapidly (e.g. using water depth data loggers or via remote sensing), modelling provides the only general approach capable of reconstructing historic patterns of hydrologic variability and simulating sensitivity to future conditions (Pyke, 2004) (see Box 1).

Examples of applications of hydrological models to reconstruct rock pool hydroregimes are presented in Hulsmans et al. (2008) and Vanschoenwinkel et al. (2009a). A similar bucket model was developed by Altermatt et al. (2009). Hulsmans et al. (2008) used model simulations to investigate long term patterns of seasonal and interannual variation in hydroregime for rock pools in southeastern Botswana. Simulations indicated large variation in individual hydroperiods (76-115\%) as well as in the number of hydroperiods per year (19-23\%). Vanschoenwinkel et al. (2009a) reconstructed the hydroregime of 36 rock pools on one outcrop in South Africa. Average predicted hydroperiod varied between three and 101 days. Predicted inundation frequency ranged from three to 17 inundations per year. Variation in predicted hydroperiod was high, with standard deviations ranging from three days for small shallow pools up to 171 days for large deep pools, resulting in a significant correlation between standard deviation on the hydroperiod, maximum depth, and pool area, respectively. Variation in number of inundations was relatively low with standard deviations ranging from two to four inundations per year. In addition, Hulsmans et al. (2008) simulated hydrological conditions associated with potential climate change scenarios and evaluated these with respect to the biological requirements of the anostracan Branchipodopsis wolfi, a peculiar inhabitant and key stone species in this habitat. It was suggested that climate change would significantly alter the rock pool hydroregime with decreasing suitability for $B$. wolfi. These findings confirmed the hydrologic sensitivity of ephemeral rock pool habitats to precipitation patterns, and their potential sensitivity to future climate change. 


\section{Box 1.- Method to assess rock pool hydroregime}

The first step in determining the hydroregime is to acquire a reliable estimate of the water balance of a pool. This procedure is much simpler for rock pools than for other temporary aquatic habitats since they occur as depressions in impermeable bedrock (usually granite or sandstone) and are often characterized by steep edges. As a result they can be idealized as buckets. For rock pools, therefore, a combination of a limited number of field calibrations and the availability of precipitation and evaporation data can be sufficient to satisfactory predict the presence of water (Hulsmans et al., 2008) or water volume in individual pools (Altermatt et al., 2009; Vanschoenwinkel et al., 2009a) from simple models. Based on the output of the model, a time series of water levels can be obtained with a daily resolution.

Once the model has been calibrated and validated by comparing its output to actual water levels of individual pools measured in the field, their hydroregime (disturbance regime) can be reconstructed using long term climatological data. From the generated water level time series, a number of hydrological variables can then be calculated such as: average hydroperiod and inundation or desiccation frequency as well as the intra and inter annual variation of these variables.

Making use of existing climate change scenarios, the effects of climate change on rock pool hydroregimes and closely related abiotic factors such as salinity can be simulated. In case the critical time periods needed for growth and reproduction for different taxa is known, one could carefully hypothesize potential effects of increased time stress or relaxation of current temporal constraints in the future on species composition, biotic interactions and, possibly to some extent, ecosystem functioning. The dependence of rock pools on precipitation directly links this habitat with the reigning climate in a region and could therefore be a sensitive barometer for climate changes.

\section{SPATIAL SETTING OF POOLS AND POOL CLUSTERS}

An important feature of rock pool systems is a well defined spatial hierarchical structure which is expressed at three different levels (Fig. 2). Populations and communities are usually assumed to be limited to the pool boundaries, although many actively dispersing pool inhabitants may travel regularly among pools during their lifespan. The first level of spatial organisation is the typical spatially clumped occurrence of rock pools arranged in clusters of potentially interacting pools (Fig. 2a). One or sometimes several of such pool clusters can often be found at the summit of dome shaped rocky outcrops or inselbergs (secondary spatial structure, Fig. 2b). These inselbergs, in turn, form isolated units embedded in a terrestrial landscape matrix of habitat which is usually unsuitable for rock pool species (tertiary spatial structure, Fig. 2c).

Inselbergs occur globally in all major biomes and are often distributed over large areas in high densities crossing multiple environmental gradients as is for instance the case in large parts of Western Australia and the Ivory Coast. The number of pools and pool clusters present on individual inselbergs is highly variable. Usually only one pool cluster is present, although large mountains such as the Korannaberg in South Africa and several outcrops in Western Australia hold many isolated clusters. The number of pools can vary between one and more than 1,000 , as is the case for some inselbergs in Western Australia. Pools typically show variable degrees of isolation and connectivity. Some methods to assess pool isolation and connectedness are suggested in Box 2. In some cases pools occur widely scattered over large areas as is the case on the giant sandstone slabs in Moab, Utah.

\section{LOCAL PHYSICAL STRUCTURE AND ABIOTIC ENVIRONMENT}

Rock pools around the world have a very similar geomorphological structure and abiotic environment. They all originate through weathering and erosion (Campbell, 1997; Dominguez-Villar, 2006), resulting in a similar geomorphology of 


\section{Box 2.- Methods to assess spatial structure.}

Two spatial variables that are informative and easy to assess are pool isolation and connectedness. Pool isolation can be calculated as the average distance to another pool in the cluster (sum of all the nearest edge to edge distances to all the other pools divided by the number of other pools). Connectedness, in turn can be quantified as the sum of all overflows arriving (and departing) from the pool in question (i.e. number of connecting elements).

Depending on the characteristics of connecting elements (length, diameter, water flow, wind direction), weighing factors can be included to improve the connectivity matrix. Similarly the size of source populations could potentially be accounted for in the light of density dependent dispersal. In more complex clusters, GIS modeling may help to calculate 'resistances' of different connections (Michels et al., 2001). The main advantage of using simple variables is that they are easy to interpret in terms of ongoing dispersal dynamics. It must, however, be noted that the presented isolation measure is only accurate when all pools present have been sampled. If only a limited number of pools are sampled, estimates of the number of neighbors that lie within a certain radius may be more informative. In order to get a complete picture of spatial patterns over different spatial scales more sensitive methods have been developed such as Principal Coordinate Analysis (PCoA; Gower, 1966; Legendre \& Legendre, 1998), Principal Coordinates of Neighbouring Matrices (PCNM; Borcard et al., 2004) and the construction of third degree polynomials of $\mathrm{X}$ and $\mathrm{Y}$ coordinates (Cottenie et al., 2003). Results obtained using these methods, however, tend to be less straightforward to interpret. Sensitive methods to detect spatial variation such as the latter, when used to explain community patterns, for instance, are also more likely to pick up 'hidden' environmental gradients which may result in overestimation of the importance of space.

the basin, only varying in surface and depth. Rock pools are usually pan or bucket shaped with a cylindrical or ellipsoid surface and variable dimensions. Weathering and erosion may lead to fusion of neighbouring pools resulting in more complex shapes (Twidale \& Corbin, 1967).

This comparable and simple environment is a major advantage as it allows for joint analysis of patterns across different spatial scales between pool systems in different regions and even across continents. A detailed overview of the chemical and physical conditions in rock pools is presented in Brendonck et al. (2001) for Southern African rock pools and at a global scale by Jocque et al (2010). In general, basins are filled with rain water, resulting in a highly diluted environment at the start of the inundation with conductivities below $10 \mu \mathrm{S} \mathrm{cm}^{-1}$, approaching those of distilled water. The generally shallow rock pools, with water depth usually varying between 5 and $30 \mathrm{~cm}$, have poor buffering capacity to environmental changes, closely follow air temperature, and also show large diurnal fluctuations in $\mathrm{pH}$ and dissolved oxygen.

\section{LOCAL BIOTIC ENVIRONMENT}

As in other types of temporary aquatic systems, rock pool animals can be roughly divided in those that permanently reside in the habitat, even during the dry phase (as resistant life stages), and those that migrate to more permanent systems when pools are drying out (Wiggins et al., 1980). The highly variable environmental conditions combined with a relatively unpredictable flooding regime select for a specialized fauna with a high tolerance to stress and often specific adaptations for surviving the dry phase. Most pool species survive via resting propagules (e.g. dormant eggs), desiccation resistant larvae or by active migration and recolonization (Wiggins et al., 1980; Brendonck \& De Meester, 2003).

Rock pools are suitable systems to study trophic interactions and food web dynamics. In contrast to the commonly quoted description of temporary pools as 'enemy-free' habitats (Fryer, 1986; Kerfoot \& Lynch, 1987), predation, in fact, is important in rock pools and has been shown to be an important community structuring fac- 
tor. Common predators in rock pools are the clawed toad (Xenopus laevis) (Hamer \& Martens, 1998) in Africa, Turbellaria (Mesostoma spp.) (Brendonck et al., 2002; De Roeck et al., 2005 ), different types of insect predators (e.g. notonectids, odonates, corixids, dytiscids (Brendonck et al., 2002) and ceratopogonid midge larvae (Vanschoenwinkel et al., unpub data). Certain predatory water mites are also common inhabitants of rock pools worldwide which colonize pools after they have been inundated (Jocque et al., 2010). Predation pressure typically increases towards the end of inundations (Schneider \& Frost, 1996; Spencer et al., 1999). Factors contributing to this pattern are delayed arrival of actively migrating predators (Jocque et al., 2007), concentration of predators due to evaporation of the water and the time lag that certain predators require to mature and become predatory. This is for instance the case with tadpole shrimps (Triops sp.) and turbellarians.

Besides predation, also competitive interactions were shown to be important in rock pools, notably between the two dominant groups of filter feeding rock pool crustaceans; fairy shrimp (Anostraca) and water fleas (Cladocera). Fairy shrimp are the dominant filter feeders early during inundation and outcompete smaller cladocerans in field enclosures (Jocque et al., in press b). The authors argued that a trade off between predation sensitivity and competitive strength provides a likely explanation why the large fast growing fairy shrimp are dominant early during inundations and are later replaced by predation resistant Cladocera. Long term observations (> 17 years) in a Daphnia metacommunity inhabiting coastal rock pools in Finland revealed how subtle niche differences in combination with frequent extinction and colonization processes mediate species coexistence in naturally fragmented habitats (Hanski, 1983; Pajunen \& Pajunen, 2007).

For an extensive review of biotic interactions in rock pools we refer to Jocque et al. (2010).

\section{DISPERSAL DYNAMICS}

The spatial structuring of rock pools (Fig. 2), provides opportunities to directly study the spatial interactions between communities and populations and quantify the exchange of species and genotypes, respectively. Different methods have been developed to intercept dispersing organisms, notably at local within cluster scales and mainly for passive dispersers (Vanschoenwinkel et al., 2008a). Little is known about the dynamics of dispersing adult aquatic insects and amphibians. Within pool clusters, passively dispersing animals are dominantly dispersed by wind and overflows between pools and to a lesser extent by animals.

During heavy rains, rock pools may overflow. This water, which may hold animals and dormant life stages, is generally lost in the surrounding landscape matrix and is expected to result in serious losses, especially for populations situated at the margin of the outcrop. Occasionally, water may flow from one pool to another, facilitating hydrochorous dispersal. For rock pools in southeastern Botswana, Hulsmans et al. (2007) quantified the number of viable dormant eggs and larvae dispersed by overflows, making use of traps (see Box 3). Up to 784 viable eggs and 301 larvae of the anostracan $B$. wolfi were captured during one single rainfall event. Trapping of dispersing propagules in overflowing water during a heavy downpour, revealed dispersal rates up to 128 eggs and 46 larvae per hour. With a similar setup, Vanschoenwinkel et al. (2008a) estimated an average dispersal rate of 4,088 propagules per channel per year for rock pools in a South African cluster.

Brendonck \& Riddoch (1999) provided first experimental evidence in support of wind as a local dispersal vector in the fairy shrimp $B$. wol$f i$ by means of sticky traps (see Box 3 ) mounted around and between rock pools in the dry season. Also using sticky traps, Vanschoenwinkel et al. (2008a) collected very high numbers of propagules (average propagule rain: 649 propagules $/ \mathrm{m}^{2}$ in one month) in a pool cluster in South Africa. Collected propagule densities, however, decreased dramatically beyond several meters from potential source populations. The importance of wind as dispersal vector was also demonstrated with the use of wind socks (see Box 3) (Vanschoenwinkel et al., 2008b). Using nine wind 
a.) Rock pools as aquatic archipelagos
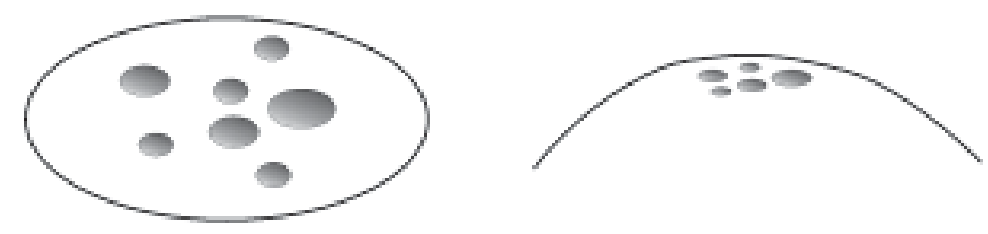

b.) Multiple pool clusters on top of a rocky outcrop

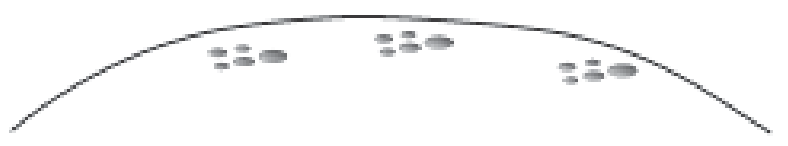

c.) Rocky outcrops as islands in the regional landscape matrix
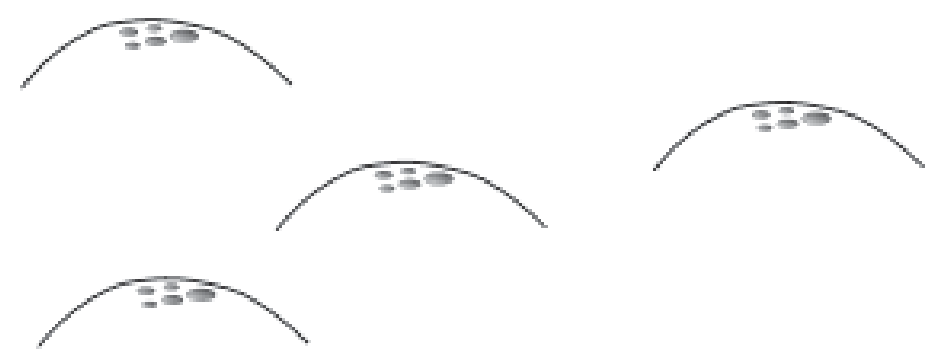

Figure 2. Different levels of spatial hierarchical organization, characteristic of freshwater rock pool habitats a.) pool clusters often situated near the summit of rocky outcrops; b.) rocky outcrops containing multiple pool clusters; c.) rocky outcrops (inselbergs) as interacting units in the regional landscape. Distintos niveles de organización jerárquica espacial, característica de los hábitats de pozas en rocas: a.) grupos de pozas frecuentemente situadas cerca de la cima de elevaciones rocosas; b.) elevaciones rocosas que contienen pozas en grupos; c.) elevaciones rocosas (inselbergs) como unidades interactivas en el paisaje regional.

socks, about 850 propagules (mostly dormant eggs) of 17 taxa were captured during one month. The key factors determining yields, were the presence of water in the pools directly affecting the level of exposure of the dormant propagule bank and the dominant wind direction. Temporal variation in wind speed, surprisingly, was not important in this study. As rock pools often occur rather exposed on the top of outcrops, wind is expected to be not only of importance for local but potentially also for long distance dispersal.
Fragmented observations support a limited potential for zoochory. Mainly amphibians such as the African clawed frog (Xenopus laevis) and potentially also aquatic insects (Van De Meutter et al., 2008) or songbirds, which only rarely visit rock pool sites, are potential vectors. Contrary to other aquatic systems in which they have shown to be important vectors (Figuerola $\&$ Green, 2002), waterfowl is largely absent. Vanschoenwinkel et al. (2008a) isolated invertebrate propagules from the faeces of African clawed 
Box 3.- Methods to measure wind (anemochorous) and overflow (hydrochorous) dispersal.

Windsocks

Windsocks can be used to collect propagules that are lifted from the substrate. The windsock design used in Vanschoenwinkel et al. (2008b) consists of a conical sock $(100 \mu \mathrm{m}$ mesh) with a diameter of $30 \mathrm{~cm}$ and a total length of $90 \mathrm{~cm}$ attached to a stainless steel frame (Fig 3). The tip of the windsock is curved and a zipper is integrated $30 \mathrm{~cm}$ from the tip to facilitate the removal of the collected samples. The metal frame consists of two stainless steel rings of 30 and $20 \mathrm{~cm}$ in diameter, respectively, connected by four $30 \mathrm{~cm}$ long crossbars. This rigid structure ensures a fixed opening of the mouth of the wind sock, even under conditions of low wind speed. The windsock is able to rotate freely around a stainless steel axis. Even with low wind speed the mouth of the sock is always directed towards the current wind direction. The whole structure can be anchored in a plastic parasol stand filled with sand.

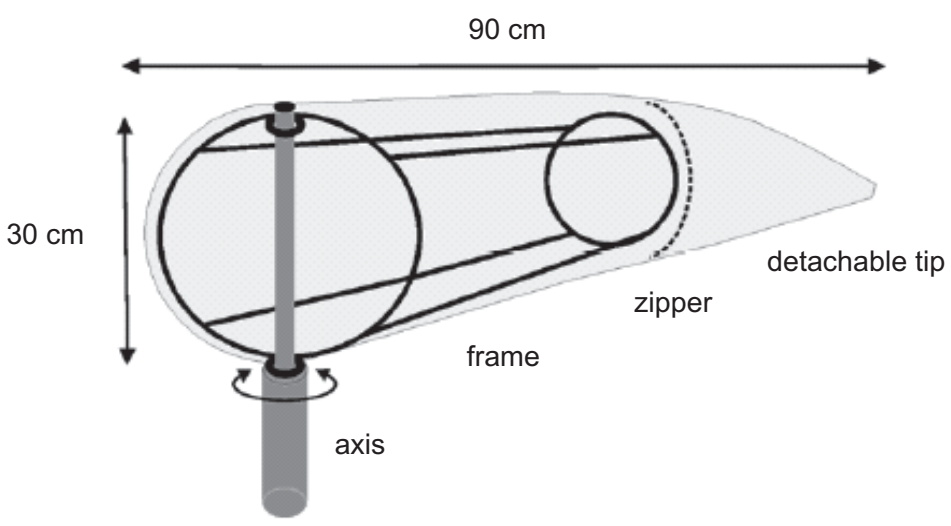

Figure. 3. Detailed schematic drawing illustrating the design of the experimental wind socks. Essential parts such as the zipper to detach the tip of the sock and the metal frame used to keep the mouth of the wind sock open at all times are indicated (figure taken from Vanschoenwinkel et al., 2008b). Diagrama esquemático que ilustra el diseño de las mangas de viento. Se han indicado las partes esenciales como la cremallera para separar la punta de la manga y el armazón de metal utilizado para mantener la boca de la manga de viento abierta en todo momento (figura tomada de Vanschoenwinkel et al., 2008b).

Sticky traps

To measure wind dispersal at the level of the rocky substrate, sticky traps can be attached at variable distances from a pool. Sticky traps exist of cardboard surfaces coated with about $2 \mathrm{~mm}$ layer of Tangletrap ${ }^{\circledR}$ insect glue (Tanglefoot company) placed in the field. The glue is more or less water resistant but heavy rains will, nonetheless, destroy the set up.

Flow traps

To measure hydrochorous dispersal, the water in eroded channels between pools can be guided through a central plastic cup lined with a fine $(64-\mu \mathrm{m})$ mesh by means of clay dams (Fig 4). Influx of wind blown propagules in dry cups should be avoided by thoroughly rinsing the cups prior to rainstorms. Cups can be removed and transported to the lab for study of collected propagules immediately after overflow events.

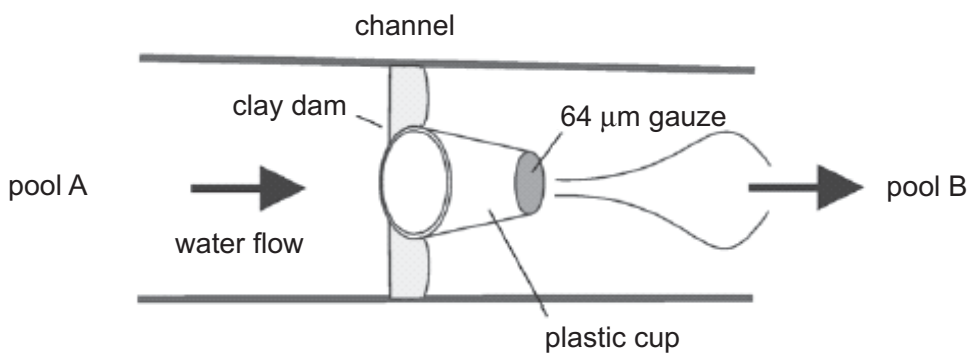

Figure. 4. Schematic diagram illustrating the experimental setup used to measure hydrochorous dispersal through channels (overflow trap). All components including the clay dam and the plastic cup lined with fine gauze are indicated (figure taken from Vanschoenwinkel et al., 2008a). Diagrama esquemático que ilustra el diseño experimental utilizado para medir la hidrocoria a través de un canal (trampa de rebosadero). Se indican todos los componentes, incluyendo el dique de arcilla con el vaso de plástico con un fondo de malla fina (figura tomada de Vanschoenwinkel et al., 2008a). 
frogs (Xenopus laevis) and counted on average 368 propagules per frog after 24 hours. Amphibian mediated dispersal was considered of limited importance as the Xenopus laevis population was small and migrations rare.

To date it largely remains unknown to what extent dispersal capacity varies among taxa and how it is related to size and shape of dispersing propagules. As an attempt to fill this gap, Vanschoenwinkel et al. (2009b) compared dispersal capacities and modes of freshwater invertebrates in a cluster of temporary rock pools in South Africa making use of a combination of windsocks (1.5 $\mathrm{m}$ above ground level) and sticky traps (ground level). Differences were detected in the composition of dispersing communities intercepted at these different altitudes. Comparison of dispersal distance distributions also revealed significant differences among taxa. Larger propagule types (e.g. adult ostracods and oribatid mites) predominantly travelled near ground level while small dormant eggs and cryptobiotic life stages of copepods were most frequently intercepted at higher altitudes (up to $1.5 \mathrm{~m}$ ) and dispersed over the longest distances. Almost all propagules were able to reach the most isolated traps in the study (30 $\mathrm{m}$ from a nearest pool) suggesting that dispersal at such local scales is not limiting. To simulate the potential movement of propagule bank fragments, differently sized artificial substrate fragments similar to dry propagule bank fragments were arranged in the dry pool basins and their inter pool movements were mapped. Both interception of dispersing natural propagule bank fragments and observed successful inter pool dispersal of artificial substrate fragments, suggested that not only dispersal of single propagules but also ground level transport of propagule bank fragments can contribute to local dispersal dynamics.

\section{META-STRUCTURES OF POPULATIONS AND COMMUNITIES}

The spatial hierarchical structure of the habitat combined with the unique opportunity to quantify patch disturbance regimes (Box 1), isolation and connectedness (Box 2) and local dispersal dynamics (Box 3) make that rock pools can be conveniently used to test predictions of metapopulation and metacommunity models. Besides the possibility to study spatial interactions between communities and populations at local scales, the ancient habitat (old rock formations) and global distribution of rock pools makes them attractive habitats for biogeographic and phylogeographic studies (see Jocque et al., 2010).

\section{Populations}

In a series of studies with increasing numbers of populations and metapopulations in southeastern Botswana, the genetic structure of the rock pool anostracan $B$. wolfi was studied by means of allozyme electrophoresis (Riddoch et al., 1994; Brendonck et al., 2000; Hulsmans et al., 2007). Rock pool sites differed in number, size and connectivity of pools. Genetic diversity was significantly lower in populations residing at the outcrop with shallower pools and shorter hydrocycles (Brendonck et al., 2000; Hulsmans et al., 2007). This could be linked to a greater incidence of extinction and recolonisation in these basins (genetic bottlenecks). Across all local populations, a significant level of population differentiation was usually revealed. More than $90 \%$ of this variation was explained by differentiation among pool clusters (metapopulations), although this differentiation did not correlate with geographic distance, or with environmental differences (Brendonck et al., 2000; Hulsmans et al., 2007). Low levels of genetic differentiation within pool clusters suggest significant levels of short distance dispersal and gene flow. Rare long distance dispersal events, possibly enhanced by founder effects, on the other hand, were most likely responsible for higher levels of differentiation among pool clusters on different outcrops.

Genetic differentiation among populations within metapopulations was low, but significant at all sites. Riddoch et al. (1994) at one site and Hulsmans et al. (2007) at three sites, detected clear isolation by distance patterns. Gene flow estimates indicated from 0.6 to 227 migrants per generation. This corresponded with direct ob- 
servations of high dispersal rates by means of overflowing pools (Hulsmans et al., 2007). Based on these allozyme data, distances of about $50 \mathrm{~m}$ appeared to be effective barriers for gene flow (Hulsmans et al., 2007).

\section{Communities}

Using the output of a hydrological model (see Box 1) combined with a detailed description of the morphometry of the study pools, Vanschoenwinkel et al. (2009a); demonstrated that both hydroregime and habitat size had unique and shared effects on temporary pool biota and that these effects depended on the dispersal mode (passive versus active) of the considered taxa. As expected, hydroregime was more important for passive than for active dispersers.

Of different metacommunity perspectives, a combination of species sorting and mass effects best explained distribution patterns in a cluster of 36 temporary rock pools in central South Africa (Vanschoenwinkel et al., 2007). The relative importance depended largely on dispersal strategy (active versus passive). Spatial variables were only important for passive dispersers and significantly explained $11 \%$ of variation in this community component. Pools connected by temporary overflows hosted more similar communities of passive dispersers than unconnected ones, while community dissimilarity significantly increased with inter pool distance. In addition, a negative curvilinear relation was discovered between taxon richness and isolation in passive dispersers. A similar differential response to spatial versus environmental variables was found between generalist and specialist species in a long term data set on invertebrate communities in coastal rock pools in Jamaica (Pandit et al., 2009). These authors contrasted metacommunity structure of generalists and specialists and concluded that the distribution of generalists responded more to regional (spatial) processes while specialists dominantly responded to local processes (species sorting). Beside mass effects and species sorting, low dispersal rates (dispersal limitation) likely affected the communities in this system. Difficulties in distinguishing the nature of spatial effects in rock pool metacommunities, which can arise due to high (mass effects) or low dispersal rates (dispersal limitation), were discussed by $\mathrm{Ng}$ et al. (2009). By comparing the importance of spatial and environmental effects at different spatial scales the authors were able to conclude that the spatial effects in their dataset most likely resulted from dispersal limitation operating among pool clusters separated by a distance of $2 \mathrm{~km}$.

\section{Succession and community assembly}

Jocque et al. (2007) studied invertebrate community assembly and dynamics in 16 ephemeral rock pools (lasting from less than a week to about one month) at two rock pool sites in Botswana. The goal of this study was to verify whether succession or replacement of species could be detected in short lived pools where early desiccation is likely to truncate community assembly. Data were collected every two days during a full inundation cycle. All communities were initially assembled by permanent residents (passive dispersers) recolonising the habitat from dormant egg banks to which actively dispersing ephemeral taxa were added later in the hydrocycle. Species replacements only occurred in a small fraction of pools, especially in those with the longest hydroperiods. Concurrent with a decrease in the densities of the anostracan $B$. wolfi, population sizes of Leberis sp. and Culicidae (Aedes sp. and Anopheles sp.) increased in these pools. Although it was possible to distinguish two successional phases at one rock pool site, community assembly was generally a gradual process determined by dispersal strategies of the inhabitants. Additional rains after initial filling triggered dispersal by active dispersers and positively influenced colonization success. A reduced hydroperiod shortened the community development down to a critical point below which lack of time eliminated the possibility of species replacements. Based on these findings, ephemeral waters were defined as aquatic habitats lacking species replacements. 


\section{RISK SPREADING STRATEGIES AND ADAPTATIONS TO VARIABLE DISTURBANCE REGIMES}

A major stress factor for permanent inhabitants of temporary rock pools, especially in arid regions, is the possibility of elimination of the population by premature drying. Persistence in this environment under time stress therefore not only requires adaptations in life history characteristics of the active population but also in hatching behavior of the resting stages.

Particularly the life history characteristics of fairy shrimp (Anostraca) in relation to the hydroregime are well studied in rock pools. Branchipodopsis species in general are real champions in racing against time to mature before the habitat disappears. Laboratory and field observations by Hamer \& Appleton (1996) revealed rapid growth and early maturation (4-6 days after hatching) of B. tridens, B. wolfi, B. dayae and B. browni (all inhabiting rock pools). Species inhabiting rock pools in the southern African Drakensberg also reached sexual maturity in a matter of days (Hamer \& Martens, 1998). Female populations of $B$. wolfi started to produce dormant eggs after five days and were fully mature within eight days in most pools (Brendonck et al., 2001). Maturation rate was faster in the shorter lived and/or more unpredictable pools (Brendonck et al., 2001). Life span of rock pool Anostraca lasted less than four (Hamer \& Appleton, 1996) or six weeks (Hamer \& Martens, 1998). Broods tended to have smaller eggs in more unpredictable pools (Brendonck et al., 2001). Brood sizes varied between 40 and 80 eggs in specimens from the Drakensberg region in South African (Hamer \& Martens, 1998).

Models developed for desert annual plants predict that high variation in reproductive success among growing seasons (Cohen, 1966, 1967, 1968) may promote selection for prolonged dormancy with hatching percentages corresponding with the chance of successful recruitment. Such delayed germination of a variable portion of the 'seed bank' can be considered an evolutionary risk spreading strategy (bet hedging) which entails that the geometric mean fitness over time can be maximized by reducing the variance in fit- ness, at the cost of the arithmetic mean fitness of each generation (Philippi \& Seger, 1989). Little empirical work has been done so far to determine the relationship between the average chance of successful recruitment and germination or hatching fractions (Philippi, 1993a,b). Scattered experimental evidence suggests that certain rock pool inhabitants may have adopted such strategies. The delayed hatching of part of the egg bank of $B$. wolfi, for example, served as a hedge against at least 16 subsequent drought catastrophes (Brendonck et al., 1998). Hatching percentages under realistic field temperatures after filling of pools $\left(20-30^{\circ} \mathrm{C}\right)$, ranged between about 3 and $20 \%$, which corresponded well with estimates of the probability of successful recruitment based on long term climatic records (Brendonck \& Riddoch, 2001). Van Dooren \& Brendonck (1998), showed that variability in hatching response even occurs in single broods and could therefore be considered a diversified bethedging strategy. Egg banks furthermore revealed conditional responsiveness to ecologically informative hatching cues (temperature, conductivity), restricting hatching to initial or additional rains, resulting in an association between hatching and the likelihood of completing a life cycle (Brendonck et al., 1998). The relatively high egg densities of egg banks of between about 1,000 and 220,000 eggs per $\mathrm{m}^{2}$, depending on season or year, illustrate the effectiveness of the reproductive and hatching characteristics of this species (Brendonck \& Riddoch, 2000).

\section{ROCK POOLS AS A MODEL SYSTEM, WHERE ARE WE NOW?}

According to Levins (1984) and Srivastava et al. (2004) a good ecological model system is characterized by the following features: tractability, generality and realism. Rock pool systems inarguably exhibit a number of characteristics which make them 'easy to use'. However, besides the practical advantages of working with small, pristine and structurally simple systems and the possibility to quantify processes which are hard or impossible to quantify in larger mo- 
re complex systems, rock pools also have the advantage that their basic properties and spatial configuration closely resemble theoretical metapopulation and metacommunity models (Bengtsson, 1989). Perhaps the most important property that makes small aquatic systems attractive to test model predictions is the presence of clear boundaries which are often highly 'fuzzy' in other systems. Short lifespan of the organisms present in rock pools and small aquatic habitats in general also allow observing population and community dynamics within a relatively short timeframe while comparable observations on larger organisms would require vast amounts of time. Due to the simple morphometry of rock pool basins and the lack of any groundwater interactions, rock pool hydrologies are simple allowing to reliably reconstruct the disturbance regime against which patterns of variation in life histories, population genetics, species richness and community structure can be interpreted.

However, despite these advantages, the specific knowledge on this habitat is limited. Rock pool systems in regions such as South America and Asia remain unstudied and the number of research groups systematically using rock pools as study habitat is also small.

A final consideration is here at place. Rock pool systems are peculiar systems which in certain aspects can be considered ecological oddballs (Srivastava et al., 2004) and some care is needed before generalizing processes and patterns observed in this habitat. Compared to other habitat types, rock pools, for instance, exhibit a severe form of disturbance in terms of a recurring dry phase. Consequently animals that occur in these habitats can all, to some extent, be considered disturbance specialists. Rock pools also generally house very small populations compared to larger habitats such as ponds and lakes and as a result may be more sensitive to external influences. Evidence also suggests that local extinctions occur relatively frequently. Contrary to most other ecosystems, genetic bottlenecks, low genetic diversity and most likely also priority effects may be common in rock pool habitats and are likely to affect the evolutionary trajectories of populations (Haag et al., 2005).

\section{REFERENCES}

ALTERMATT, F., V. I. PAJUNEN \& D. EBERT. 2009. Desiccation of rock pool habitats and its influence on population persistence in a Daphnia metacommunity. PLOS ONE, 4: 4703.

BAUDER, E. T. 2005. The effects of an unpredictable precipitation regime on vernal pool hydrology. Freshwater Biol., 50: 2129-2135.

BENGTSSON, J. 1989. Interspecific competition increases local extinction rate in a metapopulation system. Nature, 340: 713-715.

BLAUSTEIN, L. \& S. S. SCHWARTZ. 2001. Why study ecology in temporary pools? Isr. J. Zool., 47: 303-312.

BORCARD, D., P. LEGENDRE \& P. DRAPEAU. 1992. Partialling out the spatial component of ecological variation. Ecology, 73: 1045-1055.

BRENDONCK, L., B. J. RIDDOCH, V. VAN DE WEGHE \& T. VAN DOOREN. 1998. The maintenance of egg banks in very short-lived pools-a case study with anostracans (Branchiopoda). In: Evolutionary and Ecological Aspects of Crustacean Diapause. L. Brendonck, L. De Meester \& N. G. Hairston, Jr. (eds.): 141-161. Arch. Hydrobiol. (Special issues).

BRENDONCK, L. \& B. J. RIDDOCH. 1999. Windborne short-range egg dispersal in anostracans (Crustacea: Branchiopoda). Biol. J. Linn. Soc., 67: 87-95.

BRENDONCK, L. \& B. J. RIDDOCH. 2000. Egg bank dynamics in anostracan desert rock pool populations (Crustacea: Branchiopoda). Arch. Hydrobiol., 148: 71-84.

BRENDONCK, L., L. DE MEESTER \& B. J. RIDDOCH. 2000. Regional structuring of genetic variation in short-lived rock pool populations of Branchipodopsis wolf (Crustacea: Anostraca). Oecologia, 123: 506-515.

BRENDONCK, L. \& B. J. RIDDOCH. 2001. Hatching characteristics of the fairy shrimp Branchipodopsis wolfi in relation to the stochastic nature of its habitat, desert rock pools. Verh. Inernat. Verein. Limnologie, 27: 3931-3935.

BRENDONCK, L., M. HAMER, B. J. RIDDOCH \& M. SEAMAN. 2001. Branchipodosis species: specialists of ephemeral rock pools. Afr. J. Aquat. Sc., 25: 98-104.

BRENDONCK, L., E. MICHELS, L. DE MEESTER \& B. RIDDOCH. 2002. Temporary pools are not 'enemy-free'. Hydrobiologia, 486: 147-159. 
BRENDONCK, L. \& L. DE MEESTER. 2003. Egg banks in freshwater zooplankton: evolutionary and ecological archives in the sediment. Hydrobiologia, 491: 65-84.

BROOKS, R. T. 2004. Weather-related effects on woodland vernal pool hydrology and hydroperiod. Wetlands, 24: 104-114.

CAMPBELL, E. M. 1997. Granite landforms. J. Royal Soc. W.A., 80: 101-112.

COHEN, D. 1966. Optimizing reproduction in a randomly varying environment. J. Theor. Biol., 12: 119-129.

COHEN, D. 1967. Optimizing reproduction in a randomly varying environment when a correlation may exist between the conditions at the time a choice has to be made and the subsequent outcomes. J. Theor. Biol., 16: 1-14.

COHEN, D. 1968. A general model of optimal reproduction in a randomly varying environment. $J$. Ecol., 57: 219-228.

COTTENIE, K. \& L. DE MEESTER. 2003. Connectivity and cladoceran species richness in a metacommunity of shallow lakes. Freshwater Biol., 48: 823-832.

DE MEESTER, L., S. DECLERCK, R. STOKS, G. LOUETTE, F. VAN DE MEUTTER, T. DE BIE, E. MICHELS \& L. BRENDONCK. 2005. Ponds and pools as model systems in conservation biology, ecology and evolutionary biology. Aquat. Conserv., 15: 715-725.

DENNIS, B., R. A. DESHARNAIS, J. M. CUSHING \& R. F. COSTANTINO. 1997. Transitions in population dynamics: Equilibria to periodic cycles to aperiodic cycles. J. Anim. Ecol., 66: 704729.

DE ROECK, E. R. M., T. ARTOIS \& L. BRENDONCK. 2005. Consumptive and nonconsumptive effects of turbellarian (Mesostoma sp.) predation on anostracans. Hydrobiologia, 542: 103-111.

DOMÍNGUEZ-VILLAR, D. 2006. Early formation of gnammas (weathering pits) in a recently glaciated area of Torres del Paine, southern Patagonia (Chile). Geomorphology, 76: 137-147.

ELLIS, A. M., L. P. LOUNIBOS \& M. HOLYOAK. 2006. Evaluating the long-term metacommunity dynamics of tree hole mosquitoes. Ecology, 87: 2582-2590.

FIGUEROLA, J. \& A. J. GREEN. 2002. Dispersal of aquatic organisms by waterbirds: a review of past research and priorities for future studies. Freshwater Biol., 47: 483-494.

FISCHER, S., M. C. MARINONE, M. S. FONTANARROSA, M. NIEVES \& N. A. SCHWEIGMANN. 2000. Urban rain pools: seasonal dynamics and entomofauna in a park of Buenos Aires. Hydrobiologia, 441: 45-53.

FRYER, G. 1986. Enemy free space: a new name for an ancient ecological concept. Biol. J. Linn. Soc., 27: 287-292.

GILPIN, M. E. \& I. HANSKI (eds.). 1991. Metapopulation dynamics: empirical and theoretical investigations. Academic Press, London. 300 pp.

GOWER, J. C. 1966. Some distance properties of latent root and vector methods used in multivariate analysis. Biometrika, 53: 325-338.

HAAG, C. R., M. RIEK, J. W. HOTTINGER, V. I. PAJUNEN \& D. EBERT. 2005. Genetic diversity and genetic differentiation in Daphnia metapopulations with subpopulations of known age. Genetics, 170: 1809-1820.

HAMER M. L. \& C. C. APPLETON. 1996. The genus Branchipodopsis (Crustacea, Branchiopoda, Anostraca) in southern Africa. Morphology, distribution, relationships and the discription of five new species. Ann. S. Afr. Mus., 104: 311-377.

HAMER, M. L. \& K. MARTENS. 1998. The large Branchiopoda (Crustacea) from temporary habitats of the Drakensberg region, South Africa. Hydrobiologia, 384: 151-165.

HANSKI, I. 1983. Coexistence of competitors in patchy environment. Ecology, 64: 493-500.

HOLYOAK, M. \& M. LOREAU. 2006. Reconciling empirical ecology with neutral community models. Ecology, 87: 1370-1377.

HUGHES, A. R., J. E. BYRNES, D. L. KIRNBRO \& J. J. STACHOWICZ. 2007. Reciprocal relationships and potential feedbacks between biodiversity and disturbance. Ecol. Lett., 10: 849-864.

HULSMANS, A., K. MOREAU, L. DE MEESTER, B. J. RIDDOCH \& L. BRENDONCK. 2007. Direct and indirect measures of dispersal in the fairy shrimp Branchipodopsis wolfi indicate a smallscale isolation-by-distance pattern. Limnol. Oceanogr., 52: 676-684.

HULSMANS, A., B. VANSCHOENWINKEL, C. PYKE, B. J. RIDDOCH \& L. BRENDONCK. 2008. Quantifying the hydroregime of a temporary pool habitat: A modelling approach for ephemeral rock pools in SE Botswana. Ecosystems, 11: 89-100. 
JOCQUE, M., K. MARTENS, B. RIDDOCH \& L. BRENDONCK. 2006. Faunistics of ephemeral rock pools in southeastern Botswana. Arch. Hydrobiol., 165: 415-431.

JOCQUE, M., B. J. RIDDOCH \& L. BRENDONCK. 2007. Successional phases and species replacements in freshwater rock pools: towards a biological definition of ephemeral systems. Freshwater Biol., 52: 1734-1744.

JOCQUE M., B. VANSCHOENWINKEL \& L. BRENDONCK L. 2010. Freshwater rock pools: habitat characterisation, faunal diversity and conservation value. Wetlands. Freshwater Biol. (in press a).

JOCQUE, M., B. VANSCHOENWINKEL \& L. BRENDONCK. In press. Anostracan monopolisation of early successional phases in temporary waters? Fund. Appl. Limnol.

KERFOOT, W. C. \& M. LYNCH. 1987. Branchiopod communities: associations with planktivorous fish in space and time. In: Predation: Direct and Indirect Impacts on Aquatic Communities. W. C. A. S. Kerfoot (ed.): 376-382. University Press, New England.

LEGENDRE, P. \& L. LEGENDRE 1998. Numerical Ecology (second English ed.), Elsevier Science BV, Amsterdam. 870 pp.

LEIBOLD, M. A., M. HOLYOAK, N. MOUQUET, P. AMARASEKARE, J. M. CHASE, M. F. HOOPES, R. D. HOLT, J. B. SHURIN, R. LAW, D. TILMAN, M. LOREAU \& A. GONZALEZ. 2004. The metacommunity concept: a framework for multi-scale community ecology. Ecol. Lett., 7: 601-613.

LEVINS, R. 1984. The strategy of model building in population biology. In: Conceptual Issues in Evolutionary Biology. Sober, E. (ed.): 18-27. Cambridge University Press.

LINK, B. A. \& S. G. MEGASON. 2008. Zebrafish as a model for development. In: Sourcebook of Models for Biomedical research. P. M. Conn (ed.): 103-112. Humana Press. Totowa, NJ.

MARCUS, V. \& S. C. WEEKS. 1997. The effects of pond duration on the life history traits of an ephemeral pond crustacean, Eulimnadia texana. Hydrobiologia, 359: 213-221.

MICHELS, E., K. COTTENIE, L. NEYS \& L. DE MEESTER. 2001. Zooplankton on the move: first results on the quantification of dispersal of zooplankton in a set of interconnected ponds. Hydrobiologia, 442: 117-126.
MOUQUET, N. \& M. LOREAU. 2002. Coexistence in metacommunities: The regional similarity hypothesis. Am. Nat., 159: 420-426.

MOUQUET, N. \& M. LOREAU. 2003. Community patterns in source-sink metacommunities. Am. Nat., 162: 544-557.

NG, I. S. Y., C. M. CARR \& K. COTTENIE. 2009. Hierarchical zooplankton metacommunities: distinguishing between high and limiting dispersal mechanisms. Hydrobiologia, 619: 133-143.

OSTMAN, O., J. M. KNEITEL \& J. M. CHASE. 2006. Disturbance alters habitat isolation's effect on biodiversity in aquatic microcosms. Oikos, 114: 360-366.

PAJUNEN, V. I. \& I. PAJUNEN. 2007. Habitat characteristics contributing to local occupancy and habitat use in rock pool Daphnia metapopulations. Hydrobiologia, 592: 291-302.

PANDIT, S. N., J. KOLASA \& K. COTTENIE. 2009. Contrasts between habitat generalists and specialists: an empirical extension to the basic metacommunity framework. Ecology, 90: 2253-2262.

PFEIFER, M., K. WIEGAND, W. HEINRICH \& G. JETSCHKE. 2006. Long-term demographic fluctuations in an orchid species driven by weather: implications for conservation planning. J. Appl. Ecol., 43: 313-324.

PHILIPPI, T. \& J. SEGER. 1989. Hedging ones evolutionary bets, revisited. Trends Ecol. Evol., 4: 4144.

PHILIPPI, T. 1993a. Bet-hedging germination of desert annuals-beyond the $1^{\text {st }}$ year. Am. Nat., 142: 474-487.

PHILIPPI, T. 1993b. Bet-hedging germination of desert annuals-variation among populations and maternal effects in Lepidium lasiocarpum. Am. Nat., 142: 488-507.

PYKE, C. R. 2004. Simulating vernal pool hydrologic regimes for two locations in California, USA. Ecol. Model., 173: 109-127.

RIDDOCH, B. J., S. W. MPOLOKA, M. CANTRELL. 1994. Genetic variation and localized gene flow in the fairy shrimp, Branchiopodopsis wol$f$, in temporary rainwater pools in South-eastern Botswana. In: Genetics and evolution of aquatic organisms. A. R. Beaumont (ed.): 96-102. Chapman and Hall, London, U.K.

SCHNEIDER, D. W. \& T. M. FROST. 1996. Habitat duration and community structure in temporary ponds. J. N. Am. Benthol. Soc., 15: 64-86. 
SPENCER, M., L. BLAUSTEIN, S. S. SCHWARTZ \& J. E. COHEN. 1999. Species richness and the proportion of predatory animal species in temporary freshwater pools: relationships with habitat size and permanence. Ecol. Lett., 2: 157-166.

SRIVASTAVA, D. S., J. KOLASA, J. BENGTSSON, A. GONZALEZ, S. P. LAWLER, T. E. MILLER, P. MUNGUIA, T. ROMANUK, D. C. SCHNEIDER \& M. K. TRZCINSKI. 2004. Are natural microcosms useful model systems for ecology? Trends Ecol. Evol., 19: 379-384.

THERRIAULT, T. W. \& J. KOLASA. 2001. Desiccation frequency reduces species diversity and predictability of community structure in coastal rock pools. Isr. J. Zool., 47: 477-489.

TWIDALE, C. R. \& E. M. CORBIN. 1963. Gnammas. Revue de Géomorphologie Dynamique, 14: 1-20.

URBAN, M. C., M. A. LEIBOLD, P. AMARASEKARE, L. DE MEESTER, R. GOMULKIEWICZ, M. E. HOCHBERG, C. A. KLAUSMEIER, N. LOEUILLE, C. DE MAZANCOURT, J. NORBERG, J. H. PANTEL, S. Y. STRAUSS, M. VELLEND \& M. J. WADE. 2008. The evolutionary ecology of metacommunities. Trends Ecol. Evol., 23: 311-317.

VAN DE MEUTTER, F., R. STOKS \& L. DE MEESTER. 2008. Size-selective dispersal of Daphnia resting eggs by backswimmers (Notonecta maculata). Biol. Lett., 4: 494-496.

VAN DOOREN, T. \& L. BRENDONCK. 1998. The hatching pattern of Branchipodopsis wolfi (Crustacea: Anostraca): phenotypic plasticity, additive genetic and maternal effects. Adv. Limnol., 52: 219-227.
VANSCHOENWINKEL, B., C. DE VRIES, M. SEAMAN \& L. BRENDONCK. 2007. The role of metacommunity processes in shaping invertebrate rock pool communities along a dispersal gradient. Oikos, 116: 1255-1266.

VANSCHOENWINKEL, B., S. GIELEN, H. VANDEWAERDE, M. SEAMAN \& L. BRENDONCK. 2008a. Relative importance of different dispersal vectors for small aquatic invertebrates in a rock pool metacommunity. Ecography, 31: 567-577.

VANSCHOENWINKEL, B., S. GIELEN, M. SEAMAN \& L. BRENDONCK. 2008b. Any way the wind blows-frequent wind dispersal drives species sorting in ephemeral aquatic communities. Oikos, 117: $125-134$.

VANSCHOENWINKEL, B., A. HULSMANS, E. DE ROECK, C. DE VRIES, M. SEAMAN \& L. BRENDONCK. 2009a. Community structure in temporary freshwater pools: disentangling effects of habitat size and hydroregime. Freshwater Biol., 54: 1487-1500.

VANSCHOENWINKEL, B., S. GIELEN, M. SEAMAN \& L. BRENDONCK. 2009b. Wind mediated dispersal of freshwater invertebrates in a rock pool metacommunity: differences in dispersal capacities and modes. Hydrobiologia, 635: 363-372.

WIGGINS, G. B., R. J. MACKAY \& I. M SMITH. 1980. Evolutionary and ecological strategies of animals in annual temporary pools. Arch. Hydrobiol., 58: 97-206.

WILSON, D. S. 1992. Complex interactions in metacommunities, with implications for biodiversity and higher levels of selection. Ecology, 73: 1983-2000. 